\title{
El mito humanístico del letrado y la antropovisión renacentista
}

\author{
Víctor Gerardo Rivas
}

\begin{abstract}
Si pudiéramos imaginarnos una encarnación de la disonancia - ¿y qué otra cosa es el ser humano?-, esa disonancia necesitaría, para poder vivir, una ilusión magnífica que extendiese un velo de belleza sobre su esencia propia.
\end{abstract}

Nietzsche

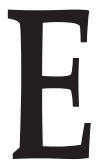

s el humanismo una de esas nociones que todos comprendemos por sentido común pero que con dificultad se ciñen a los rigores de una definición clara y concisa en cuyos términos podamos englobar la plétora de acontecimientos y transformaciones culturales que se diseminó por Europa desde el segundo tercio del siglo XIV italiano, cuando Petrarca se encuentra en su plenitud, hasta fines del siglo XVI, cuando los núcleos de la producción intelectual se desplazan del Mediterráneo hacia el norte. En tan dilatado espacio de tiempo se dan cita las tendencias más dispares, por lo que hablar del humanismo como un fenómeno unitario resulta prácticamente imposible. Así, en lo que sigue el humanismo designará una concepción peculiar del ser humano que en algunas de sus manifestaciones ha implicado una actitud polémica respecto a los fundamentos históricos de Occidente. ${ }^{1}$

Sobre la puerta de entrada a la cultura moderna, se yergue el humanismo, el movimiento artístico-filosófico que por primera vez en la historia de las ideas

${ }^{1} C f$. lo anterior con estas palabras de Alan Bullock: "Como hipótesis de trabajo he considerado al humanismo no como una escuela de pensamiento o como una doctrina filosófica, sino como una amplia tendencia, una dimensión de pensamiento, sentimiento y creencia, un continuado y vivo debate dentro del cual en cualquier momento histórico pueden encontrarse muy diferentes, y a veces opuestas, concepciones, unidas más que por una estructura unificada, por la certeza de compartir ciertas asunciones y preocupaciones ante algunos problemas y tópicos, que cambian en distintos momentos históricos. Tradición humanista es la mejor expresión que he podido encontrar para expresar esa amplia concepción". (Alan Bullock, La tradición humanista en Occidente. Trad. de Enrique Fernández-Barros. Madrid, Alianza, 1989, p. 11.) 
concibió al hombre como creador. Para la Antigüedad grecolatina, a pesar del heroísmo que podía incluso inmortalizarlo, el hombre se hallaba siempre a merced de los poderes cósmicos que se corporalizaban en los dioses; sus obras, aun las más grandiosas, estaban circunscritas a una naturaleza que lo desbordaba. Por ello, cualquier apología del ser humano concluía en un recordatorio de su mortalidad:

¡De cuantas maravillas

pueblan el mundo, la mayor, el hombre!

[...]

Su avance no detiene azar alguno,

y no hay dolencia que le salga al paso

que a soslayar no acierte.

De sólo un mal no escapa: de la muerte. ${ }^{2}$

Por lo que toca al judaísmo, las cosas se presentan incluso con mayor dureza. Cuando un irritado Yavé decide acallar de una vez por todas las quejas de Job, lo que hace es desplegar con soberbio ademán el orden de la creación para mostrar que en él no tiene el hombre parte alguna y que por lo tanto debe mantenerse en los estrechos lindes de su propio destino sin clamar al cielo por las desgracias que le caen encima:

¿Quién es este que empaña mi providencia con insensatos discursos? Cíñete, pues, como varón tus lomos. Voy a preguntarte para que me instruyas. ¿Dónde estabas al fundar yo la tierra? ¿Quién determinó, si lo sabes, sus dimensiones? ¿Quién tendió sobre ella la regla? ¿Sobre qué descansan sus cimientos o quién asentó su piedra angular entre las aclamaciones de los astros matutinos y los aplausos de todos los hijos de Dios? ${ }^{3}$

Ante tan formidable demostración de poder, ¿qué otra cosa sino humillar la frente en el polvo, como lo hace Job? "He hablado a la ligera. ¿Qué te voy a responder? Pondré mano a mi boca. Una vez hablé; no responderé más; dos veces, y no añadiré palabra". ${ }^{4}$

Como vemos, ambos pasajes establecen una línea de continuidad entre el poderío divino, por un lado, $\mathrm{y}$, por el otro, la nimiedad del hombre que priva

${ }^{2}$ Sófocles, Antígona, verso primero. México, Ed. de Aurelio Espinosa Polit, S. J., p. 219 .

${ }^{3}$ Biblia, Job, 38: 2-7.

${ }^{4}$ Ibid., 39: 34-35. 
a éste del carácter creador o, por lo menos, de la omnipotencia que en cambio gozan los dioses (aun cuando, como en el caso de los helénicos, no sean propiamente creadores del cosmos). Por ello, siempre que la Antigüedad grecolatina o la judaica se ocuparon del estudio de lo humano, lo circunscribieron a la ineluctable ley de la natura o a los omnímodos designios de Dios, único ser, en última instancia, capaz de crear. Semejante visión, huelga decirlo, se mantuvo vigente y aun se fortaleció a lo largo del Medioevo, durante el cual el tema del hombre se derivó por fuerza de cuestiones mucho más relevantes, $v$. $g r$., la esencia de la Verdad, del cosmos o de Dios, cuestiones que le otorgaron una importancia bastante relativa a lo antropológico en el orden total del saber.

¿Por qué entonces se constituyó lo humano en el objeto de un enorme interés para la época renacentista, al punto que diversos autores identifican ambos fenómenos, Renacimiento y humanismo ${ }^{55}$ Por su complejidad, esta pregunta desborda con creces nuestro marco de referencia, mas sí debemos anotar que la cultura europea experimentó una serie de insólitas transformaciones a fines del medievo, las cuales implicaron poner en duda la autoridad de los dos bastiones sociales, la Iglesia y el Imperio. Y aunque tal vez para nosotros no sea eso un motivo suficiente para la emergencia del interés por el hombre, hay que considerar que "para los 'hombres de la Edad Media', la Iglesia y el Imperio eran, indudablemente, más que instituciones sociales en el sentido actual de la palabra, necesidades en cierto modo naturales destinadas a durar tanto como la propia humanidad". ${ }^{6}$ Al entrar en crisis el poder efectivo del Imperio a favor de las rivalidades dinásticas y de la feroz reluctancia de los príncipes a obedecer a un poder central y con el descrédito de la Iglesia a resultas del gran cisma que escindió a la jerarquía eclesiástica entre 1378 y 1417 , se abrió un vacío en la cosmovisión medieval, vacío inimaginable tanto para los antiguos como para el propio pensamiento cristiano que en las obras de aquéllos se nutría. La ley natural -que englobaba a la social-determinaba el lugar de cada individuo conforme a un ordenamiento metafísico eviterno que incluía la necesaria existencia de las instituciones sociales; al tambalearse el carácter sacral de éstas, la ley pareció insuficiente para garantizar la armonía transcendente del cosmos y la acción creadora humana cobró una insólita relevancia que le permitió integrarse a los fundamentos de la sociedad. De

\footnotetext{
${ }^{5}$ Como lo indico a continuación en el texto, no analizaré a fondo si el Renacimiento y el humanismo son equiparables, aunque sí quiero aclarar que si lo que renació fue la cultura antigua y ésta, como lo acabo de mostrar, no concibió al hombre como creador, mal puede identificarse lo renacentista como lo humanístico, que parte de la creatividad humana.

${ }^{6}$ Andrés Chastel y Roberto Klein, El humanismo, p. 11.
} 
este modo, la génesis del humanismo se corresponde con la temporalización de lo humano, temporalización que, insisto, no remite a la forma actual de concebir a la sociedad (es decir, como un conglomerado que se define en virtud de una ley profana -la constitución, justamente-), sino que afecta a la estructura metafísica del universo.

En conformidad con este nuevo marco histórico y conceptual, los humanistas echaron mano de los mitos clásicos $(v$. $g r$., el de Prometeo o el de Ícaro) y de ciertos pasajes de los Evangelios (como el del pecado original) que hasta entonces se habían interpretado como símbolos de la impotencia creadora del hombre, para trocarles el sentido y convertirlos en parábolas morales que reflejaban un nuevo tipo de valorar los vínculos del hombre con el universo, al tenor del cual el ser humano -en cuanto especie, mas sobre todo en cuanto individuo- se destacó del resto de las criaturas. Este proceso exigió asimilar los dos mundos, el sacro y el profano, de modo tal que el propio fin de la acción humana cambió de sentido: ya no fue simplemente un débil trasunto de la creatividad divina y se perfiló más bien como el medio para expresar la voluntad del hombre.

Este proceso de consolidación humanística se encuentra en la base de la obra en la que con mayor entusiasmo se hace la apología de la creatividad humana, De la dignidad del hombre de Pico de la Mirándola. La obra comienza por mentar que en el hombre se unifican todas las demás criaturas con Dios, pues reúne rasgos de todas ellas y también de éste. Pero no es sólo el hombre un compendio del universo, es también el único de sus integrantes que carece de un lugar determinado en la creación, por lo que aunque se encuentre bajo el dictado de la ley natural, puede moldearla conforme a su voluntad, según le dice Dios a Adán al insuflarle la vida, en el que quizá sea el pasaje más célebre de la obra:

Para los demás, una naturaleza contraída dentro de ciertas leyes que les hemos prescripto. Tú, no sometido a cauces algunos angostos, te la definirás según tu arbitrio al que te entregué [...] Ni celeste ni terrestre te hicimos, ni mortal, ni inmortal, para que tú mismo, como modelador y escultor de ti mismo, más a tu gusto y honra, te forjes la forma que prefieras para ti. ${ }^{7}$

Para analizarlo mejor, destaquemos las ideas más significativas del pasaje anterior: 1. La natura del hombre es fruto directo de su esfuerzo personal, por lo que aun la inmortalidad depende de él más que de la voluntad divina; 2 . La

${ }^{7}$ Pico de la Mirándola, De la dignidad del hombre. Ed. de Luis Martínez Gómez. Madrid, Editora Nacional, 1984, p. 105. 
inmarcesible dignidad humana es idéntica a su libertad de acción y no a la obediencia inapelable de los designios divinos; 3. Las limitaciones del hombre dejan de verse como fruto de su caída y se visualizan más bien como posibilidades de desarrollo; 4. Los valores supremos para el hombre serán su "gusto y honra", por lo que la virtud consistirá en el placer, y 5. Ya no habrá criterios válidos para todos sino cada uno los definirá conforme a su parecer (lo cual, como lo acabamos de recordar en el párrafo anterior, tampoco significa que se abrogue la ley natural sino que se compagina con la participación humana).

De esta guisa, la exaltación del hombre es ante todo la del individuo creador y versátil al que arrebata la pasión por la gloria, pasión que a los ojos del medievo era pecaminosa. Tomemos en cuenta que mientras que para los medievales la simple idea de lo voltario tenía una connotación nefasta (se le representaba con la imagen de la rueda de la fortuna que tras elevar precipita en la ruina), para los humanistas la gloria es la oportunidad de mostrar la propia virtud: a la imagen de la rueda la sustituye la nave que llega a buen puerto tras las peores tempestades; realizar el sumo bien y glorificarse en el siglo son idénticos. Claro está, si el individuo ha de engrandecerse con sus obras, habrá menester del aplauso de los demás para realizar el sentido más alto de su naturaleza, el social; ya que "[...] lo que los hombres deseaban entonces era volverse inmortales en su personalidad terrena", ${ }^{8}$ el individuo y la sociedad eran las dos caras de una misma moneda.

Este enaltecimiento del individuo coincide con otra de las preocupaciones axiales de los humanistas: superar la oposición entre la vida activa y la contemplativa, la última de las cuales recibió desde la Antigüedad la palma. Según Platón y Aristóteles, el fin del hombre es la contemplación beatífica de la verdad, ${ }^{9}$ tesis que el cristianismo medieval retomó a través de la patrística y que se mantuvo incólume hasta el Renacimiento, cuando la revaloración de la creatividad abonó la vía activa. Esta identidad entre lo activo y lo creador es fundamental, pues ella desbrozó el camino para la formulación de un nuevo paradigma cultural en sustitución del teólogo medieval; hablamos justamente del letrado, quien, sin dejar de ocuparse de materias religiosas y filosóficas, es ya una figura profana que cubre dos campos muy diversos: el gobierno del Estado y la educación personal. El letrado, canciller y pedagogo a un tiempo, ya no actúa en relación directa con la Iglesia pero tampoco defiende sin más

${ }^{8}$ Ágnes Heller, El hombre del Renacimiento. Barcelona, Península, 1980, p. 211.

${ }^{9} C f$. la entrada relativa a la "contemplación" en Ferrater Mora, Diccionario de filosofía, vol. I. Madrid, Alianza, 1984, pp. 614-615, donde a ese concepto se asocian significados místico-religiosos muy importantes para comprender el trasfondo cultural que la interpretación humanística implicó en su momento. 
los intereses seculares; su labor es conducir a los hombres sin distinción de credo, de sexo, de estado o de cuna, a la luz de la sabiduría que se percibe en el interior de cada quien. Con un aliento entre mesiánico y utópico, el letrado exige la purificación del culto, la renovación de la fe y hasta la abolición de privilegios que ofenden la natura creadora del individuo.

La vinculación del carácter social y de la creatividad se pone de manifiesto de manera particular en la coincidencia de dos fenómenos artísticos: el auge del retrato y del intercambio epistolar a partir de la segunda mitad del siglo XV. El objeto de la imagen plástica y de la verbal era el autoconocimiento con miras a la perfección moral pero también al prestigio social. Incluso las cartas que trataban temas personales se difundían por toda Europa, pues, lejos de ser meras portadores de noticias, constituían exposiciones más o menos rigurosas de problemas teóricos de varia índole o, en el mejor de los casos, ejercicios de estilo que con frecuencia se convertían en auténticas autobiografías que se redactaban de acuerdo con arquetipos poéticos. Así,

[...] un género literario, la epístola, y un género plástico, la medalla, parecían especialmente apropiados para difundir a mayor escala y con menor costo el nuevo culto de la inmortalidad. La medalla es, en esto, sobre todo, reveladora [...] En el anverso, el retrato, en el reverso, una figura simbólica y una inscripción relacionada con ella, constituían la definición ideal del personaje, representado en resumen elíptico. La invención de los reversos de las medallas solía confiarse a un hombre de letras $[\ldots]^{10}$

Con la necesidad de engrandecimiento de la individualidad, es lógico que la palabra cobrara inusitada relevancia en el desarrollo ulterior del humanismo como tradición cultural. No olvidemos que cuando en 1512 aparece en Italia el vocablo umanista, sirve para nombrar una serie de actividades que se relacionan sobre todo con el estudio de la retórica:

El término renacentista studia humanitatis, que nosotros traducimos como humanidades, comprendía en el siglo XV un grupo de materias académicas - gramática, retórica, historia, literatura y filosofía moral-, cuyo estudio implicaba la lectura de textos latinos clásicos anteriores al cristianismo, traducciones latinas de obras griegas y, aunque no era muy común, textos originales griegos. ${ }^{11}$

${ }^{10}$ A. Chastel y R. Klein, op. cit., p. 24.

${ }^{11}$ A. Bullock, op. cit., pp. 15-16. 
Lo curioso del caso es que el programa educativo humanista ponía de relieve más que nada la conveniencia del cultivo literario de los gobernantes, con lo que dignificó el poder y se reveló que el extraordinario privilegio del saber se basaba en su resonancia política; tal vez como en ninguna otra época desde la Antigüedad, la oratoria fue el nervio de la vida social, al punto que se consideraba más elevado un discurso que contuviese proposiciones heterodoxas o francamente heréticas pero que se estructurase de acuerdo con los paradigmas clásicos que uno que incitase a la piedad por medio de un estilo vulgar. El saber al que aspiraba el humanista era en última instancia no un conocimiento abstracto sino eminentemente práctico: "Ciencia, arte y técnica comulgaban así, en principio al menos, en el humanismo; pero humanismo, ciencia y técnica se fundían a su vez en el arte". ${ }^{12}$

Quiero hacer hincapié en el modo en que el humanismo entendió el binomio saber/poder, ya que tiene una consecuencia muy importante: el esfuerzo por desechar las discrepancias y reforzar los puntos en común entre las diversas interpretaciones de un mismo fenómeno, pues, al fin y al cabo, el universo responde a la unidad que el propio ser humano impone por medio de su acción, la cual puede tener tantas maneras de entenderse como sujetos posibles. De ahí que resulte absurdo aferrarse a una sola manera de definir las cosas, incluso en el caso de la religión, terreno donde los humanistas trabajaron a favor del ecumenismo. Para ellos era mucho más importante fundar en la razón el comportamiento hacia los demás y hacia uno mismo que el definir con rigor un sistema dogmático de creencias acerca de Dios.

En suma, la gran tarea de los humanistas, la que culminó justo en el letrado como paradigma del sabio, fue la invención de una dignidad humana equiparable a la libertad divina. En este aspecto, el humanismo constituyó una fuerza intelectual en estrecha alianza pero también en profunda competencia con la Iglesia, pues su manera de enfocar las relaciones entre el hombre y su Creador dejaban atrás los fundamentos institucionales del cristianismo, ya que no los doctrinales. Esta cuestión involucró a otro movimiento afín al humanismo que, no obstante, guardó siempre su distancia respecto a éste, es decir, el hermetismo. No en balde, Marsilio Ficino, el maestro directo de Pico de la Mirándola, tradujo en 1463 el Poimandrés, supuesta obra de Hermes Trismegisto. Humanistas hubo, empero, que no tuvieron nada que ver con el hermetismo y que recalcaron más bien la necesidad de partir sólo del cristianismo como la religión por antonomasia. Uno de ellos es, justamente, Erasmo, que

${ }^{12}$ Stefan Zweig, Erasmo de Rotterdam, p. 69. Un desarrollo mucho más extenso de esta cuestión, lo emprendo en el capítulo I, apartado B, de mi libro "La sombra fugitiva": la poética del "precipicio" en Primero sueño y en la antropovisión barroca, que en breve publicará la UNAM. 
en sí encarna la quintaesencia del humanismo y a quien, por ende, debemos considerar la personificación suprema del letrado.

Tenemos, pues, un mito humanista, el letrado, cuyas implicaciones más hondas atañen, por un lado, a la religiosidad y, por el otro, a la apología de la creatividad humana. Este mito es al unísono la base de una moral sui generis que subordina la conducta a la elección racional de ciertas normas que garanticen la gloria de cada uno en la convivencia pacífica con los doctos; por último, el ideal establece que la sabiduría exige una forma armónica para expresarse con claridad. Estos tres aspectos, la religiosidad, la moral hedonista y el cultivo de la retórica tuvieron un peso diferente de acuerdo al humanista en turno, aunque en conjunto sostienen un paradigma vital que presenta al letrado de modo simultáneo como el creador de sí mismo y como el cristiano auténtico. Esta doble identidad es la que explica en gran medida el carácter conflictivo que el humanismo jugó en la inmensa conmoción religiosa que sirvió de telón de fondo a los orígenes de la modernidad, conmoción que significó el fin del propio mito cuyo sentido general hemos querido desplegar hasta aquí. 